\title{
Kobberrullen (3Q15) fra Qumran i dens litterære sammenhæng
}

\author{
Professor, dr.theol. \\ Jesper Hogenhaven
}

\begin{abstract}
The Copper Scroll from Qumran Cave 3 (3Q15) can be meaningfully read as a literary text within the context of ancient Jewish writings generally and of the Qumran library in particular. In 3Q15 a communicative situation is envisaged, with an authoritative voice giving instructions to an addressee, who is imagined as moving around from place to place to retrieve the hidden valuables at various locations. Many of the geographical and personal names mentioned derive their significance from their function in older literary traditions. The state of the Promised Land as described in 3Q15 is one of impurity and desolation, awaiting eschatological redemption. The impression of a desolate ruined landscape is corroborated by references to hiding-places that are regularly presented as deserted ruins, abandoned water installations, and tombs. The treasures described in 3Q15 belong to Solomon's temple; and the text should be read against the background of the welldocumented legends about those treasures.
\end{abstract}

Keyword: Copper Scroll 3Q15 - Qumran - Massekhet Kelim - Dead Sea Scrolls - Temple Treasures - Lindian Chronicle - Jewish Legends.

Den generelle opfattelse af håndskrifterne fra Qumran har ændret sig markant på de snart 70 år, der er gået siden de første fund blev gjort i 1947. Fokus var fra begyndelsen på de bedst bevarede hule 1-håndskrifter, der enten var bibelske (eller bibelsk genskrivning) eller vidnede om den særlige Qumran-teologi, som gerne betegnes "sekterisk". Efterhånden som hele materialet fra hulerne er blevet kendt, har det vist sig, at her er tale om et bibliotek, der også i en langt bredere forstand afspejler den antikke jødedoms mangfoldighed i perioden ned mod vor tidsregnings begyndelse. Gennem Qumran-litteraturen har vi fået udvidet vort førstehåndskendskab ikke kun til en Qumranbevægelse, der muligvis kan have været noget af et særstykke i datiden, men også til jødedommen i almindelighed. Det gør bestemt ikke tekstsamlingen - som vi efter alt at dømme skal forestille os må være blevet til over et længere tidsrum - mindre væsentlig.

En af de tekster, som forskerne har haft vanskeligt ved at indplacere i Qumran-bibliotekets kontekst, er Kobberrullen fra hule 3 (3Q15). Teksten, der skiller sig ud i kraft af at være en skriftrulle af kobber, er en fortegnelse over skjulte kostbarheder, en slags skattekort. Genren 
har ingen paralleller i resten af Qumran-samlingen. Nogle forskere har argumenteret for, at Kobberrullen må være blevet anbragt i hule 3 på et andet tidspunkt end de øvrige skriftruller, og at den må stamme fra en helt anden sammenhæng; men skriftets datering synes at svare til resten af håndskrifterne. Spørgsmålet er, hvordan en sådan skattefortegnelse kan forstås inden for rammerne af den kontekst, hvor den faktisk er fundet. I det følgende vil jeg argumentere for, at Kobberrullen kan læses som en litterær, fiktiv tekst, og at dens indhold har sammenhæng med motiver, som vi kender fra andre antikke jødiske tekster, nemlig legenderne om de skjulte kostbarheder fra Salomos tempel. Dette legendestof bliver i Kobberrullen - ligesom i andre jødiske tekster - tolket ind i en eskatologisk forventning om den sande tempelkults og det rette Israels genoprettelse ved tidernes ende.

\section{Fundet af Kobberrullen. Tekstens form og indhold}

Kobberrullen blev fundet i 1952 i hule nr. 3 ved Khirbet Qumran af et hold arkæologer under ledelse af Roland de Vaux og William L. Reed. ${ }^{1}$ Manuskriptet bestod af to ruller af stærkt oxideret kobber, den ene oven på den anden, der lå op ad en klippevæg, tæt på indgangen til den delvis sammenstyrtede hules indre rum. Oprindelig må rullen have bestået af tre tynde sammennittede plader $(30 \mathrm{~cm}$ høje og hver $80 \mathrm{~cm}$ lange), der tilsammen må have udgjort et langt bånd (240 $\mathrm{cm})$. Før eller under sammenrulningen er den ene plade gået løs; og man har valgt at rulle metallet sammen til to ruller, en større og en mindre. Først i 1955-1956 kunne rullerne åbnes på College of Technology i Manchester. ${ }^{2}$ Manuskriptet befinder sig i dag på The Jordan Museum i Amman.

1. Fundet blev gjort i forbindelse med en gennemsøgning af hulerne ved Qumran, organiseret af de tre Jerusalem-baserede forskningsinstitutioner L'École Biblique et Archéologique Française, American School of Oriental Research og Palestine Archeological Museum. Holdet, der fandt Kobberrullen, blev ledet af Henri de Contenson fra l'École Biblique. Se Roland de Vaux, "Exploration de la region de Qumrân. Rapport préliminaire”, RB 60 (1953), 540-561.

2. Fremgangsmåden var at skære de to ruller op i mindre strimler (i alt 23 stykker af let varierende størrelse). Processen er beskrevet i H. Wright Baker, "Notes on the Opening of the 'Bronze' Scrolls from Qumran", Bulletin of the John Rylands Library, Manchester 39 (1956-1957), 45-56. En forkortet udgave er trykt i: Józef T. Milik, "Le rouleau de cuivre de Qumrân. Traduction et commentaire topographique", $R B$ 66 (1959), 321-357; "The Copper Document from Cave III of Qumran: Translation and Commentary", Annual of the Department of Antiquities of Jordan 4-5 (1960), 137-155; "Le rouleau de cuivre provenant de la grotte 3Q (3Q15)", Les 'petites grottes' de Qumrân, red. Maurice Baillet m. fl., Discoveries in the Judaean Desert of Jordan 
Håndskriften kan med gode palæografiske argumenter, støttet på andre daterbare indskrifter, tidsfæstes til omkring midten af 1 . årh. e. $\mathrm{Kr}^{3}$ Anvendelsen af kobber er højst usædvanlig; manuskriptet minder mest af alt om en imitation i metal af det kendte skriftrulleformat (normalt læder eller papyrus). ${ }^{4}$

Uddrag af teksten blev publiceret af Józef T. Milik allerede i $1956 .{ }^{5}$ Foreløbige udgaver af hele teksten i 1959-1960 fulgtes i 1962 af den "officielle" tekstudgave i Discoveries in the Judaean Desert of Jordanserien (Milik 1962). John M. Allegro, der havde været medvirkende ved rullens åbning i Manchester, publicerede en alternativ tekstudgave i $1960 .^{6}$ I årene 1994-1996 foregik en omfattende restaurering og konservering af Kobberrullen på Électricité de la Frances Valectralaboratorium. I forbindelse med dette arbejde sørgede Émile Puech i 2006 for en ny tekstudgave, baseret på de bedste tilgængelige fotografier og en fornyet kollationering af originalmanuskriptet. ${ }^{7}$

Kobberrullens tekst har klare lighedspunkter med en liste eller et katalog, idet den består af en række korte afsnit, der hver især beskriver en lokalitet, hvor bestemte kostbarheder er skjult. Stort set hele teksten (fordelt på 12 kolonner) er bevaret. I de første kolonner (I-III) er der ved slutningen af visse afsnit anført to eller tre græske bogstaver. ${ }^{8}$ De indledende linjer giver et indtryk af stilen:

III (Oxford: Clarendon 1962), 199-302 (H. Wright Baker, "Notes on the Opening of the Copper Scrolls from Qumran”, 203-210).

3. Se Frank Moore Cross, "Excursus on the Palaeographic Dating of the Copper Document”, Milik 1962, 217-221 (217). Cross daterer skriften til 25-75 e. Kr. Milik $(1962,217)$ foreslår derimod en lidt senere dato, 30-130 e. Kr.

4. Man kan henvise til gammeltestamentlige eksempler på brug af varigt materiale med det formål at sikre skriftlige budskaber bestand og gyldighed. Lovens tavler (2 Mos 31,17) er det bedst kendte eksempel, jf. Es 8,1; 30,7, Hab 2,2. Allerede de Vaux $(1953,558)$ pegede på romerske love og traktater indgraveret på bronzetavler som en analogi. Callie Williamson ("Monuments of Bronze: Roman Legal Documents on Bronze Tablets", Classical Antiquity 6 (1987), 160-183) har vist, at det primære formål med denne type inskriptioner er symbolsk eller religiøst: Indgravering på bronze og ophængning i templer eller på offentlige steder sikrer tekstens gyldighed og bestand. Hensigten har derimod ikke været praktisk, da læsbarheden oftest er ringe eller ikke-eksisterende.

5. Józef T. Milik, "The Copper Document from cave III, Qumran”, BA 19 (1956), 60-64.

6. John M. Allegro, The Treasure of the Copper Scroll. The Opening and Decipherment of the Most Mysterious of the Dead Sea Scrolls. A Unique Inventory of Buried Treasure (London: Routledge and Kegan Paul Ltd 1960).

7. Émile Puech, "Le rouleau de cuivre de la grotte 3 de Qumrân (3Q15)", Le Rouleau de cuivre de la grotte 3 de Qumrân (3Q15). Expertise - Restauration - Épigraphie. Vol. I, red. Daniel Brizemeure m. fl., STDJ 55/I, Leiden: Brill 2006), 169-227.

8. Der er ikke givet nogen fuldt tilfredsstillende forklaring på de græske bogstavers betydning eller funktion i 3Q15 I-IV. De minder om forkortede personnavne. Se 
I $1-8$

$$
\begin{aligned}
& \text { בחריבה שבעמק עכור תחת } \\
& \text { המעלות הבואת למזרח אמות שחריבת עכור חתות }
\end{aligned}
$$

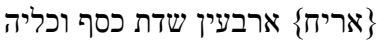

$$
\begin{aligned}
& \text { משקל ככרין שבעשרה KEN } \\
& \text { בנפש בנדבך השלישי עשתות מכריות }
\end{aligned}
$$

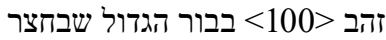

$$
\begin{aligned}
& \text { הפרסטלון בירך קרקעו סתום בחליא } \\
& \text { נגד הפתח העליון ככרין תשע מאת ספרון בירום בחלי }
\end{aligned}
$$

I Horebbe i Akors dal under vejene, som fører mod øst, 40 alen: En kiste med sølv, hvis samlede vægt er sytten talenter. KEN I den tredje række sten: 100 guldbarrer. I den store cisterne i forgården med den lille kolonnade helt i bunden, lukket mod den øvre åbning med et lag sten: 900 talenter.

Teksten er imidlertid ikke blot en opremsning af gemmesteder og skatte, men henvender sig i 2 . person til en adressat, der får instruktioner om, hvor og hvordan de pågældende skatte skal findes:

II $13-15$

בברכא שבמזרח כחלת במקצע

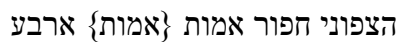

ככרין > >צפוני > >פור

I bassinet øst for Kohlit ved det nordlige hjørne - grav ... fire alen: 22 talenter.

Undertiden giver teksten ret detaljerede instruktioner om, hvordan adressaten skal finde vej:

X 5-7

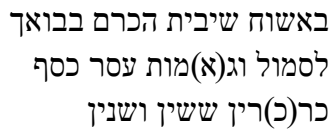

I vandreservoiret i Bet-ha-Kerem, når du går ind, ti fod til venstre: 62 talenter sølv.

Matthew Richey, "The Use of Greek at Qumran: Manuscript and Epigraphic Evidence for a Marginalized Language”, DSD 19 (2012), 177-197 (189-195). 
Og i et enkelt tilfælde finder vi et forbud mod at ødelægge det fundne:

VIII 1-3

$$
\begin{aligned}
& \text { בא]מא שבדרך מזרח בית } \\
& \text { ה]אוצר שמזרח אביה משרח } \\
& \text { (?)כלי דמע וספרין אל תב/רקעם }
\end{aligned}
$$

Ved [akvæ] dukten langs vejen øst for skatkammeret øst for Akija: beholdere til afgiftsgaver og skriftruller, ødelæg dem ikke!

Kobberrullen opererer således med en kommunikativ situation, hvor en unavngiven adressat skal bevæge sig fra sted til sted og hente de skjulte skatte frem fra deres gemmesteder. Teksten har dermed karakter af et itinerar, der viser vej gennem det beskrevne landskab. Den stemme, som taler gennem tekstens instruktioner, giver indtryk af at besidde en høj grad af autoritet og en detaljeret viden om samtlige gemmesteder. Skattene kan inddeles i to hovedkategorier, nemlig dels guld og sølv (Talenter eller guld- og sølvbarrer, gerne med angivelse af mål) og dels sakrale/kultiske genstande. Den oftest nævnte type er "afgiftsgaver" (כלי דמע). I et enkelt tilfælde (I 9) er "afgiftsgaver" specificeret som "flasker" (לגין), "præstelige klæder" (אפרדת), "skatten fra det syvende år" (האצר השבע) og "den anden tiende efter indløsning" (מעשר שני מפוגל). Det virker oplagt at forbinde denne type kostbarheder med templet.

Milik slog allerede i sine første præliminære publikationer fast, at teksten måtte placeres inden for den fiktive folkloristiske genre (Milik 1956, 62-63; jf. Milik 1962, 278-283). Også Frank Moore Cross og Sigmund Mowinckel pegede tidligt på de jødiske legender om skattene fra Salomos tempel som kontekst for Kobberrullen. ${ }^{9}$ Andre forskere som Karl Georg Kuhn, André Dupont-Sommer og John M. Allegro argumenterede til gengæld for, at skattene måtte have et historisk grundlag - enten måtte det dreje sig om Qumran-samfundets ejendom eller om skatte fra det andet tempel. ${ }^{10}$ Generelt er tendensen

9. Frank Moore Cross, The Ancient Library of Qumran and Modern Biblical Studies (New York: Doubleday \& Company 1956), 16-17, Sigmund Mowinckel, "The Copper Scroll - An Apocryphon?” JBL 76 (1957), 261-265.

10. Karl Georg Kuhn, "Les rouleaux de cuivre de Qumrân", RB 61 (1954), 193205; "Der gegenwärtige Stand der Erforschung der in Palästina neu gefundenen hebräischen Handschriften 33. Bericht über neue Qumranfunde und über die Öffnung der Kupferrollen", ThLZ 81 (1956), 541-546; André Dupont-Sommer, "Les rouleaux de cuivre trouvés a Qoumran", RHPhR 151 (1957), 22-36; John M. Allegro, The Dead Sea Scrolls. The Story of the recent manuscript discoveries and their momentous significance for students of the Bible (Harmondsworth: Penguin Books 1956), 184; Allegro 1960, 60-62, 120-129. Dupont-Sommer mente, at skatten 
gennem de seneste årtier gået $\mathrm{i}$ retning af større tilslutning til tesen om Kobberrullen som et autentisk dokument. Denne bevægelse udgør i en vis forstand et modstykke til den mere generelle skepsis, når det handler om historiciteten af antikke kilders beretninger og referencer. ${ }^{11}$

tilhørte essæerne, der praktiserede fælleseje og derfor kan have akkumuleret store former over årene. Den samme opfattelse delte Kuhn (1954) og Allegro (1956) i begyndelsen. Begge ændrede dog synspunkt til, at der var tale om tempelskatte gemt før Jerusalems fald i 70 e.Kr. (Kuhn 1956; Allegro 1960).

11. Al Wolters ("History and the Copper Scroll", Methods of Investigation of the Dead Sea Scrolls and the Khirbet Qumran Site: Present Realities and Future Prospects, red. Michael O. Wise m. fl. (New York: The New York Academy of Sciences 1994), 285-298 (291)) kunne i 1994 opsummere situationen med ordene: "A scholarly consensus seems to be emerging that the Copper Scroll is an authentic record of ancient treasure, to be dated to around 68 C.E., and that its treasures belonged either to the sectarians of Qumran or the Temple in Jerusalem". Talsmænd for skattens historiske karakter tæller bl.a. Ernest-Marie Laperrousaz ("Remarques sur l'origine des rouleaux de cuivre découverts dans la grotte 3 de Qumrân”, RHR 159 (1961), 157172), Ben-Zion Luria (הגילת נחושת ממדבר יהודה) (Jרורה לחושר) (Jerusalem: Israel Bible Research Society (החבורה לחקר המקרא בישראל)/Kiryat Sefer 1964)), Manfred R. Lehmann ("Identification of the Copper Scroll based on its technical terms", RevQ 5 (19641966), 97-105; "Where the Temple Tax Was Buried", BAR 19/6 (1993), 38-43), Bargil Pixner ("Unravelling the Copper Scroll Code: A Study on the Topography of 3Q15", $\operatorname{Rev} Q 11$ (1982-84), 323-361), Al Wolters ("Apocalyptic and the Copper Scroll", JNES 49 (1990), 145-154; Wolters 1994), P. Kyle McCarter ("The Mysterious Copper Scroll: Clues to Hidden Temple Treasure?" Bible Review 8, No. 4 (1992) 34-41, 63-64 (63-64); “The Copper Scroll Treasure as an Accumulation of Religious Offerings”, Wise m. fl. (1994), 133-148), Hartmut Stegeman (Die Essener, Qumran, Johannes der Täufer und Jesus. Ein Sachbuch (Freiburg-Basel-Wien: Herder 1993), 104-108), Judah K. Lefkovits (The Copper Scroll (3Q15): A Reevaluation. A New Reading, Translation, and Commentary, STDJ 25 (Leiden-Boston-Köln 2000), 459-469), and Émile Puech (Puech 2006). For skattefortegnelsen som fiktion argumenterer bl.a. Joachim Jeremias (“The Copper Scroll from Qumran”, ET 71 (19591960) 227-228 (228), Hans Bardtke ("Qumrān und seine Probleme. Teil II. 2. Die Kupferrollen”, ThR 33 (1968), 185-204), Leslaw Morawiecki (“The Copper Scroll Treasure. A Fantasy or Stock Inventory?” The Qumran Chronicle 4 (1994), 169174), Hanan Eshel og Zeev Safrai (אילו אוצרות נרשמו במגילת הנחושת?, Cathedra 103 (2007), 7-20) og Jesper Høgenhaven ("Geography and Ideology in the Copper scroll (3Q15) from Qumran”, Nordic Light on the Dead Sea Scrolls. Proceedings of the Nordic Network in Qumran Studies 2003-2006, red. Anders Klostergaard Pedersen m. fl., STDJ 80 (Leiden-Boston: Brill 2009), 83-106). 


\section{Litterære paralleller til Kobberrullen}

Milik henviser til to middelalderlige tekster som de mest nærliggende analogier til 3Q15 - en arabisk fortegnelse over skjulte skatte fra Egypten og en jødisk tekst, den såkaldte Massekhet Kelim, der opregner kostbarhederne fra Salomos tempel og deres gemmesteder (Milik 1962, 278-279). ${ }^{12}$ Den egyptiske skattefortegnelse består af instruktioner, givet i 2 . person til en unavngiven adressat, der får besked om, hvordan han skal finde frem til en række skjulte skatte. Itinerar-strukturen minder med andre ord om Kobberrullens:

I Biba - søg en kirke opkaldt efter Maria, du kan kende den på dens to altre. Se imellem de to altre efter en marmorplade med mange indskrifter. Flyt den, og under den vil du finde en hulning med tusind denarer, kirkens kar og kostbare skatte... (Kamal 1907, 8-9; cf. Milik 1962, 279).

I almindelighed er instruktionerne her langt mere detaljerede end i 3Q15, ligesom de udviser en markant interesse for magi og besværgelser, der er uden parallel i Kobberrullen. Massekhet Kelim er en fortællende tekst og ikke et itinerar; med sin jødiske baggrund er den naturligvis tættere på Kobberrullens univers end den arabiske skatteliste. Massekhet Kelim skelner imellem "helligdommens kar" (הכלים של בית המקדשי) og "de rige skatte, som var i Jerusalem" (עושר האוצרות שהיו בירושלים). Den førstnævnte kategori er associeret med det allerhelligste i templet og med ørkenvandringen og åbenbaringen på Sinaj:

Dette er de genstande, som blev helliget og gemt (המוקדשים והגנוזים), da helligdommen blev ødelagt: Boligen, forhænget, den hellige lysestage, vidnesbyrdets ark, præsten Arons blomst af guld og hellige diadem, doms-brystskjoldet, sølvtrompeterne, keruberne, brændofferalteret,

12. Den arabiske tekst med fransk oversættelse foreligger i: Ahmed Bey Kamal, Livre des perles enfouies et du mystère précieux au sujet des indications des cachettes, de trouvailles et de trésors (Cairo: Imprimerie de l'Institut Français d'Archéologie Orientale 1907). Den hebraiske tekst til Massekhet Kelim er overleveret i to versioner, hvoraf den ene findes i trykte udgaver fra Europa i 1600-tallet, den anden på et par marmortavler fra Beirut, hvis alder og proveniens henstår i det uvisse. En kritisk udgave er: Józef T. Milik, "Notes d'épigraphie et de topographie palestiniennes", RB 66 (1959), 550-575 (567-575). En engelsk oversættelse er tilgængelig i: James R. Davila, "The Treatise of the Vessels (Massekhet Kelim)", i: Old Testament Pseudepigrapha: More noncanonical Scriptures, red. Richard Bauckham m fl. (Grand Rapids/ Cambridge: Eerdmans 2013), 393-409. 
åbenbaringsteltets forhæng, gaflerne, kanderne, bordet, forhænget ved indgangen, bronzealteret, Arons hellige klæder, som ypperstepræsten iførte sig på forsoningsdagen, bjælderne og granatæblerne, som var på kappens slæb, de hellige genstande, som Moses lavede på Sinajs bjerg ved de hellige bud, staven og krukken med manna.

Disse ting fra templet bliver "helliget" eller "udsondret", gemt af vejen på et særligt sted nær Karmels bjerg og noteret ned "på en bronzetavle" (על לוח נחושת). Den anden kategori, de "rige skatte", kendetegnes som "de genstande, som jorden tog imod" (הכלים לקחה הארץ); og størstedelen af teksten opregner, hvordan de bliver skjult på en række forskellige steder, primært i Mesopotamien.

Denne opdeling i Massekhet Kelim er bemærkelsesværdig i forhold til Kobberrullen, hvor de allerhelligste ting fra templet slet ikke nævnes, men som i princippet kunne læses som en liste over "de genstande, som jorden tog imod", om end det geografiske perspektiv er et andet end i den middelalderlige tekst.

En interessant antik analogi er Lindos-krøniken fra 99 f. Kr., en monumental fortegnelse fra Lindos-templet på Rhodos over votivgaver skænket til helligdommens gudinde Athena Lindia. ${ }^{13}$ En fortale nævner udtrykkeligt, at nogle af de opregnede gaver er gået tabt; og formålet med fortegnelsen er klart nok at forherlige Lindos-templet og dets strålende fortid, som inskriptionen dokumenterer med kildehenvisninger. Flere af de gaver, der nævnes, knyttes sammen med kendte figurer fra fortiden:

De, der drog med Tlapolemos mod Ilion: Ni skjolde, ni daggerter, ni stormhuer, ni par benskinner. På skjoldene var skrevet: “De, der drog med Tlapolemos mod Ilion til Athena Lindia, af byttet fra Troja”. Som Gorgon nævner i bog elleve af sit værk Om Rhodos, Gorgosthenes i sit brev, Hieroboulos i sit brev (Lindos-krøniken IX, Higbie 2003, 25).

Tlapolemos er i Illiaden søn af Herakles og leder ni skibe fra Rhodos. Her har Lindos-krøniken fundet sit afsæt for at citere eller skabe en tradition om, at de hjemvendte helte skænker en votivgave til Lindos-

13. Teksten er tilgængelig i en kritisk udgave i: Carolyn Higbie, The Lindian Chronicle and the Greek Creation of the Past (Oxford: Oxford University Press 2003). Lindos-krøniken er skevet på en stele, der blev fundet i 1902 og udgravet af den danske arkæolog Christian Blinkenberg, der betegnede teksten som en 'krønike' (Higbie 2003, 155-159). Fortegnelsen over votivgaver er kombineret med en fortegnelse over gudinden Athena Lindias epifanier, knyttet til Lindos-helligdommen. James R. Davila $(2013,396)$ peger på Lindos-krøniken som den nærmeste litterære parallel til Massekhet Kelim. 
templet. Brugen af tallet ni ligner en indirekte henvisning til Illiadens ni skibe. Uden mange ord får krøniken således etableret en forbindelse til den glorværdige fortid (Higbie 2003, 222). Dette træk kan minde om Kobberrullens mange referencer til sted- og personnavne kendt fra den bibelske tradition. ${ }^{14}$

\section{Litterære træk ved teksten}

Flere forskere har været tilbøjelige til at betragte Kobberrullen som en ikke-litterær tekst. I reglen peger man på tekstens "tørre", nøgterne katalog- eller liste-præg. ${ }^{15}$ Andre har derimod argumenteret for, at teksten indeholder træk, der peger i retning af en litterær gestaltning af teksten. Således viser Ruth Fidler i en artikel fra 2002, at Kobberrullens forfatter gør brug af inclusio-teknik, idet der er en række overensstemmelser imellem begyndelsen og slutningen af rullens tekst. ${ }^{16}$ Herudfra er det nærliggende at sætte de stednavne, der nævnes henholdsvis i begyndelsen (עמק עכור, Akors dal, I 1) og i slutningen af teksten (הר גריזין, Garizims bjerg, XII 4) og deres bibelske konnotationer over for hinanden: Akors dal er i fortællingerne om Kana'ans erobring forbundet med forbrydelse, vrede og straf (Jos 7), medens Garizim i den samme fortællesammenhæng er stedet for den guddommelige velsignelse (Jos 8). Indlednings- og afslutningsafsnittene i Kobberrullen synes således at spille på stednavnenes symbolske betydning og at angive en bevægelse fra forbandelse til velsignelse (Fidler 2002, 223).

14. Mere generelt har Michael O. Wise peget på ligheder imellem Kobberrullen og antikke tempelinventarlister (Michael O. Wise, "David J. Wilmot and the Copper Scroll”, Copper Scroll Studies, red. George J. Brooke \& Philip R. Davies, JSP Supplement Series 40 (Sheffield: Sheffield Academic Press 2002), 291-310. Wise henviser også til Betfage-indskriften og den aramæiske Megillat Táanit, en fortegnelse over faste- og sørgedage. Her synes lighederne med Kobberrullen dog begrænset til teksternes almene karakter af "lister".

15. Karakteristisk i så henseende er Al Wolters' formulering: "The simple fact is that it [3Q15] is a dry, unimaginative, and extremely concise list, which has no literary virtue apart from a utilitarian precision and a regular pattern" (Wolters 1990, 151).

16. Stednavnet Kohlit forekommer begge steder (I 9; XII 10), ligesom der nævnes skjulesteder under trappetrin (I 1-2; XII 4), "afgiftsgaver" (כלי דמע, I 9; XII 6-7), en "kiste" (שדא, I 3; XII 5), referencer til kostbarhedernes "vægt" (משקל, I 4; XII 9) og opsummeringer (med brug af udtrykket כל, "det hele", I 10; XII 7). Jf. Ruth Fidler, "Inclusio and Symbolic Geography in the Copper Scroll”, Brooke \& Davies 2002, 210-225. 
Indtrykket af en litterær komposition forstærkes af bogens udtrykkelige referencer til "bøger" eller "skriftruller". Vi så før, hvordan skriftruller spillede en vigtig rolle i den passage, hvor adressaten instrueres i at passe særlig godt på ikke at ødelægge disse. En bemærkelsesværdig henvisning til en anden bog afslutter Kobberrullens tekst:

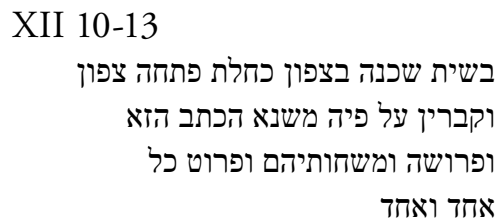

I krypten ved den glatte klippe nord for Kohlit, hvis åbning vender mod nord med grave ved indgangen: En afskrift af dette dokument med forklaring, mål og fortegnelse (13) over hver enkelt ting.

Henvisningen forlener teksten med et skær af troværdighed og underminerer samtidig effektivt alle forsøg på at forbinde teksten håndfast med eksterne forhold ved at indskyde den nævnte - nøjagtigere - "afskrift" som et ekstra led. Endvidere fremstår denne skriftrulle, der nævnes som det sidste objekt i Kobberrullens lange gennemgang af kostbarheder, som adressaten skal opsøge og fremdrage, i denne sammenhæng som et symbolsk udtryk for visdom og indsigt - den samme visdom og indsigt, som hele vejen igennem skriftets tekst er indeholdt i den anonyme autoritative "stemme", der giver adressaten sine instruktioner. Ved at være repræsenteret gennem bogrullen i det sidste gemmested, der beskrives, bliver visdommen på en måde det endelige eller ultimative mål for adressatens lange søgen, altså den genstand, som det hele i virkeligheden drejer sig om. ${ }^{17}$

17. En tredje reference til "bøger" i 3Q15 er VI 5, der omtaler "en krukke med en skriftrulle i” (שם קלל בו ספר אחד). Der optræder desuden en stribe henvisninger til skriftlige dokumenter i forbindelse med Kobberrullens omtale af "afgiftsgaver" (כלי דמע). Fem gange følges dette udtryk af henvisningen בתכן אצלן/אצלם, som bedst oversættes "med deres fortegnelse (hos dem)". Milik oversatte med "tout près de là", idet han forstod תכן som "mål", "kvantitet", her i betydningen "(lille) afstand". Afstandsangivelsen hører ifølge Milik til den følgende tekst. Da udtrykket altid følger lige efter en reference til "afgiftsgaver" (כלי דמע), giver det bedre mening at opfatte det som en beskrivelse af det foregående. Mange mener, at der i stedet for כתבן skal læses "skriftligt dokument”. Som Puech (2006, 188-189) har vist, kan תכן dog også betegne "opgørelse" "sammentælling” og i sammenhængen betegne et dokument, der følger med afgiftsgaverne. 


\section{Kobberrullens geografi og landskab}

En analyse af geografien bag teksten peger også i retning af, at Kobberrullens fortegnelse må ses i et litterært lys. Ud af 22 egentlige stednavne i Kobberrullen er de 18 navne, der også forekommer i Det Gamle Testamente og/eller Apokryferne eller i Talmud (stednavnet "Kohlit"). De fem personnavne i teksten refererer alle til kendte gammeltestamentlige figurer: Absalom (X 12), Salomo (V 6.8), Zadok (X 17; XI 3), Job (X 8) og Akija (VIII 3). ${ }^{18}$ Jeg har andetsteds søgt at vise, hvordan en række af de stednavne, der henvises til, med stor sandsynlighed er valgt ud fra de nævnte steders funktion i det bibelske fortællestof. ${ }^{19}$

Henvisningen til Akors dal i tekstens første beskrivelse skal med stor sandsynlighed læses som en reference til Akan-fortællingen i Jos 7, der handler om et tyveri af genstande, belagt med band, og den ender med, at Akan med sin familie, sine dyr og sine ejendele bliver både stenet og brændt. Over hans lig rejses et mindesmærke i form af en stendynge, som "ligger der den dag i dag" (Jos 7,26)). Akan-episoden markerer en krise i forholdet imellem Jahve og Israel, hvor det centrale projekt - israelitternes erobring af det forjættede land - er direkte truet. I profetlitteraturen (Es 65,10; Hos 2,17) er Akors dal genstand for forjættelser, knyttet til Israels eskatologiske genoprettelse. Tilsvarende må stednavnet "Absaloms minde" (יד אבשלום) referere til beretningen i 2 Sam 18,18, hvor notitsen om den stenstøtte, Absalom lod rejse for sig selv, følger lige efter beretningen om hans død og begravelse. Som i Jos 7 nævnes her et monument, der består "den dag i dag" (עד היום הזה). I begge tilfælde er der tale om personer, der straffes med en voldsom død og en irregulær begravelse under en stendynge. Som Akan-episoden udgør også Absalom-episoden et kritisk punkt i det overordnede fortællende forløb. ${ }^{20}$ Tilsvarende har også stednavnet Kedron (VIII 8) både en negativ og en positiv betydning i GT: Ke-

18. Akija henviser formentlig til den levit, der ifølge 1 Krøn 26,20 har opsyn med skatkamrene i Guds hus og skatkamrene til helliggaverne (MT: אחיה). DO 1992 bygger på en rettet tekst (אחיהם, jf. LXX: $\alpha \delta \varepsilon \lambda \varphi 01 \alpha v \tau \omega v)$ og oversætter: "deres brødre".

19. Høgenhaven 2009; In a Ruin in the Valley of Trouble: The Metaphorical Geography of the Copper Scroll (under udgivelse).

20. Motivet irregulær begravelse synes også at spille en rolle for brugen af stednavnet Bet Shan (i Kobberrullens version: בית שם, XII 6), der rummer mindelser om episoden, hvor Sauls lig bliver hængt på bymuren, hvorefter israelitterne til sidst brænder det (1 Sam 31). Til gengæld synes betegnelsen "ypperstepræstens vadested" מגזת הכוהן הגדול), VI 14-VII 1) at referere til fortællingen om israelitternes overgang over Jordan, hvor der efterlades et varigt monument som i Jos 7; 2 Sam 18. 
drondalen er stedet, hvor illegitime kultgenstande deponeres og tilintetgøres, og er dermed forbundet med urenhed, idet netop ødelæggelsen af disse genstande samtidig har en positiv, rensende karakter; og Jer 31, hvis overordnede tema er Israels fremtidige genoprettelse, specificerer udtrykkeligt, at Kedrondalen med dens urenhed og grave skal indgå i det område, som en dag bliver helligt for Jahve.

Et ejendommeligt træk ved Kobberrullens geografiske perspektiv er, at Jerusalem og templet aldrig nævnes ved navn til trods for, at flere lokaliteter tydeligvis er associeret med byen og specifikt med tempelområdet. I tekstens sammenhæng giver denne fortielse af navnet et indtryk af, at Jerusalem nærmest skal besøges i hemmelighed, som om byen er ødelagt og delvist utilgængelig eller måske behersket af fjender. Indtrykket støttes af, at adressaten instrueres om at hente kostbarheder og genstande, der har med tempeltjenesten at gøre ("afgiftsgaver af guld og sølv, stænkeskåle, bægre, offerskåle og kander” כלי כסף וזהב של דמע מזרקות כוסות מנקיאות קסאות הכל שש מאות ותשעה), III 2-4), "afgiftsgaver og klæder" (כלי דמע ולבושין, III 8)), men som siges at ligge gemt under jorden og således ikke er i brug. Bygninger, der fungerer som orienteringspunkter ("det gamle vaskerhus" og "træmagasinernes forgård" (בית המדה הישן, II 3 og חצר בתי העצין, II 5)) peger klart på området omkring templet; men hverken templet eller de nævnte bygninger synes at være i brug. ${ }^{21}$

I Kobberrullens overordnede itinerar-struktur er det tydeligt, at Jerusalem er et vigtigt sted: Adressaten føres derhen i alt tre gange. Ved de første to besøg passeres Kohlit på vejen såvel derhen som derfra; dette sted synes at fungere som slags base eller tilflugtssted uden for Jerusalem. ${ }^{22}$ Det tredje besøg i Jerusalem afslutter en længere vandring gennem Kedrondalen og når en slags højdepunkt i den udførlige beskrivelse af Zadoks grav (X 17-XI 8).

De kostbarheder, som Kobberrullen beskriver, er gemt i bygninger og monumenter og i naturlige skjulesteder dannet af landskabet (huler, kløfter osv.). Flere af de bygninger, der nævnes, beskrives som for-

21. Man kan også læse מרה ("lærer", "mester”) i stedet for מדה ("vasker") II 3. Cf. Puech 2006, 183.

22. Stednavnet Kohlit (כחלת), der er det hyppigst forekommende toponym i 3Q15, er ikke nævnt i bibelske tekster eller i nogen anden Qumran-tekst. Det er måske identisk med det כוחלית, der nævnes bQiddushin 66A som scenen for en konflikt imellem Alexander Jannaeus og de skriftlærde (Josefus har en tilsvarende beretning med Johannes Hyrkan i skurkerollen (Antiquitates XIII 288-298)). Referencer til "Kohlit-yssop" (אזוב כוחלית) i Talmud hjælper ikke til at identificere stedet. Milik (1962, 274-275, 280-281 ) forbinder Kohlit med det 'Ein Kohel ved Karmel-bjerget, som nævnes i Massekhet Kelim (Jf. Davila 2013, 400 med note 22). Puech (2006, 175, note 49) foreslår en identifikation med Tell es-Sultan nord for Jeriko. 
ladte eller forfaldne: ${ }^{23} \mathrm{I}$ almindelighed indeholder Kobberrullen ikke særligt detaljerede beskrivelser af bygningsværker eller monumenter; men det generelle indtryk, læseren får, støtter forestillingen om et øde landskab, hvor bygninger er forladte og i forfald. Et stort antal af de gemmesteder, teksten opregner, har karakter af underjordiske lokaliteter: huler, krypter og kløfter. ${ }^{24}$ Denne type lokaliteter, der umiddelbart appellerer til fantasien optræder i mange fortællinger som skjulesteder for mennesker eller genstande. En række skatte er skjult i cisterner, akvædukter og lignende indretninger, der har med vandforsyning at gøre. Her synes installationerne i flere tilfælde at være ude af brug: I den "store cisterne i forgården med søjlegangen" befinder de der deponerede 900 talenter sig i muren "ved siden af bunden" (בירך קרקרעו, I 8). Det siger sig selv, at instruktionerne til adressaten om at lokalisere skatten i dette tilfælde forudsætter, at der ikke er vand i cisternen. Akvædukter og cisterner udgør af og til synlige orienteringspunkter i landskabet. ${ }^{25}$ At flere af installationerne ikke er i brug længere, bidrager til det generelle indtryk af et øde landskab.

Påfaldende mange skatte siges at ligge gemt på steder, der er associeret med gravpladser. Kostbarhederne kan være skjult i selve graven eller gravmonumentet (I 5; III 11-12; V 13; XI 8; XI 9), eller gravpladserne kan tjene som orienteringspunkter i landskabet, der hjælper til at lokalisere gemmestederne (XI 16; XII 11). ${ }^{26}$ Den begravelsesplads, der får den mest udførlige beskrivelse, er Zadoks grav:

\section{17-XI 8}

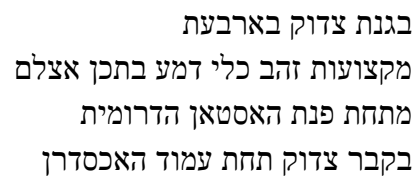

בגנת צדוק בארבעת

מקצועות זהב כלי דמע בתכן אצלם בארבת

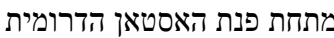

בקבר צדוק תחת עמוד האכסדרן פנת הדרומית

\footnotetext{
23. Den første lokalitet, teksten nævner, er en "lille ruin" (חריבה) i Akors dal (I 1). Det følgende gemmested - lokaliseret til Kohlit - er en "ruinhob" (תל I 9).

24. Mange af skjulestederne er tilsyneladende naturlige, medens andre virker som udgravede fordybninger. II 3 (במערת בית המדה הישן, "i hulen i det gamle skatkammer”) forbinder en hule med en bygning, hvad der kan lede tanken hen på en form for udgravet kælder. Huset kan naturligvis også være bygget oven på en naturligt dannet hule. VI 1 (בערת העמוד[,", "i søjlehulen") synes det at dreje sig om en hule i landskabet, som lokaliseres ved hjælp af en arkitektonisk detalje, formentlig en enlig søjle, der kunne være en rest af et (forladt og delvis sammenstyrtet?) bygningsværk. 25. Hanan Eshel har fremsat en række velbegrundede forslag til identifikation af flere af akvædukterne i Kobberrullen. Se Hanan Eshel, "Aqueducts in the Copper Scroll”, Brooke \& Davies 2002, 92-107.

26. Stedsbetegnelserne "Absaloms minde" (יד אבשלום, X 12, se ovenfor) og "dronningens bolig" (משכן המלכא, V 11) kan også hentyde til gravpladser eller -monumenter.
} 


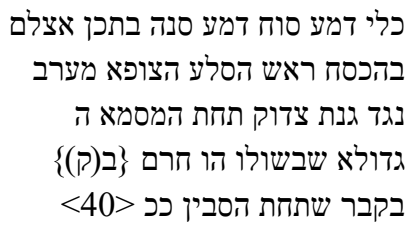

I Zadoks gård på de fire sider: Guld og beholdere til afgiftsgaver med deres fortegnelse. Under det sydlige hjørne af søjlegangen i Zadoks grav under søjlen i forkammeret: Beholdere til afgiftsgaver af fyrreharpiks og afgiftsgaver af sennes med deres fortegnelse. I stykket på toppen af klippen, der vender mod vest overfor Zadoks gård under den store sten i dens afløb: Ting, der er lagt band på. I graven under gallerierne: 40 talenter.

Den prominente rolle, Zadoks grav synes at spille, kan formentlig bedst forklares ved Zadok-skikkelsens betydning for forestillingerne om en legitim ypperstepræstelig linje og funktion.

Grave som skjulesteder for kostbarheder, i særdeleshed kendte fortidige personers grave, er et kendt motiv i antikken. Josefus fortæller, hvordan Johannes Hyrkan under en fjendtlig belejring åbner Davids grav og tager 3000 talenter. Herodes gør et lignende forsøg på at plyndre Davids og Salomos sarkofager, men bliver på overnaturlig vis hindret i sit forehavende. ${ }^{27}$ På et mere generelt plan understøtter de mange referencer til gravpladser som gemmesteder i 3Q15 naturligvis det indtryk af forladthed og øde, der kendetegner det beskrevne landskab. Dertil kommer, at netop disse lokaliteter er associeret med død og kultisk urenhed, et aspekt, de, som vi har set, deler med flere af tekstens stednavne.

\section{Kobberrullens kontekst I: Legender om skattene fra Salomos tempel}

Det giver således god mening at opfatte Kobberrullen som en litterær tekst, der beskriver kostbarheder, som for en stor dels vedkommende er associeret med Jerusalems tempel. Det landskab, hvor skattene er skjult, er beskrevet som ødelagt og mennesketomt - det virker, som om templet er ude af funktion - og udvalget af stednavne fra den litterære tradition kunne se ud til at pege i retning af et eskatologisk perspektiv

27. Josefus, Antiquitates VII 393; XIII 249; Bellum I 61 (Hyrkan); Antiquitates XVI 179-182 (Herodes). 
som tekstens forståelsesramme. Den mest nærliggende kontekst for en sådan beskrivelse, er, som mange fortolkere har gjort opmærksom på, de antikke jødiske legender om skattene fra Salomos tempel.

Det Gamle Testamente fortæller intet om hvad der skete med de mest centrale hellige genstande fra Salomos tempel i forbindelse med eksilet og Jerusalems fald: Pagtens ark og åbenbaringsteltets skæbne omtales ikke med et ord i hverken Kongebøgernes eller Krønikebøgerens beretninger om babyloniernes indtagelse af Jerusalem..$^{28} \mathrm{I}$ den ikke-kanoniske jødiske litteratur er der til gengæld flere beretninger om, hvad der sker med disse ting fra templet. Anden Makkabæerbog beretter således, hvordan præsterne umiddelbart før eksilet skjuler den hellige ild, som efter hjemkomsten genfindes under Nehemias (2 Makk 1,18-22). Forvaringen af den hellige ild og den mirakuløse genopdagelse sikrer kontinuiteten imellem den tidligere og den fornyede offerkult. Anden Makkabæerbog inddrager endvidere profeten Jeremias i forestillingerne om de hellige genstandes forvaring: Jeremias fører åbenbaringsteltet og arken ud til det bjerg, Moses var gået op på, da han så ind i Guds land:

Og da Jeremias var kommet derud, fandt han en hule (oikov $\alpha v \tau \rho \omega \delta \varepsilon$ ), og han bragte teltet og arken og røgelsesofferalteret derind og spærrede indgangen ( $\tau \eta v \theta v \rho \alpha v \varepsilon v \varepsilon \varphi \rho \alpha \xi \varepsilon)$. Nogle af dem, der var fulgt efter, gik senere derhen for at mærke sig vejen, men kunne ikke finde den. Da Jeremias erfarede det, bebrejdede han dem det og sagde: "Stedet vil forblive ukendt, indtil Gud igen samler sit folk og lader barmhjertighed råde. Så vil Herren igen lade disse ting komme for dagen, og Herrens herlighed vil komme til syne ( ledes skyen, sådan som den også viste sig på Moses’ tid og sådan som Salomo bad om det, for at stedet kunne fyldes med hellighed".

(2 Makk 2,1-8)

Beretningen har fokus på den eskatologiske genoprettelse, der vil indebære en tilbagevenden til herligheden fra Moses' dage. Gemmeste-

28. Det nærmeste, vi kan siges at komme på en reference til arken i denne forbindelse, er udsagnet Klages 2,1 om, at Jahve ikke "huskede på sin fodskammel" på sin vredes dag (ולא זכר הדם רגליו ביום אפו), der i hvert fald kan læses som en henvisning til, at pagtens ark gik tabt ved templets ødelæggelse. Jf. John Day, "Whatever Happened to the Ark of the Covenant?", Temple and Worship in Ancient Israel: Proceedings of the Oxford Old Testament Seminar, red. John Day (London/ New York: T \& T Clark 2007), 250-269 (263). Fortællingernes tavshed er så meget mere påfaldende, som de viser arken stor interesse i andre sammenhænge (1 Sam 5-6; 2 Sam 6-7; 1 Kong 8; 1 Krøn 15-17; 2 Krøn 5), og som de beretter forholdsvis udførligt om, hvad der sker med andre genstande fra Jerusalems tempel (2 Kong 24,13; 25,13-15; Jer 52,19). 
dets hemmelige og anonyme karakter er vigtigt for beretningen: Stedet kan ikke findes før Gud beslutter, at genoprettelsens tid er inde.

Også Vitae prophetarum (VitaJer 9-15) har en overlevering om Jeremias som den, der gemmer arken af vejen. Horisonten for arkens forvaring på et ukendt sted er her som i 2 Makk 2 eskatologisk. Gemmestedet er her "i ørkenen, hvor arken først var"; og først ved opstandelsen ( $\varepsilon v \tau \eta \alpha v \alpha \sigma \tau \alpha \sigma \varepsilon \imath$ ), når Moses og Aron vender tilbage, skal arken og lovens tavler igen komme til syne. En beslægtet legende findes i den Syriske Barukapokalypse. Baruk er her umiddelbart før babyloniernes indtagelse af Jerusalem blevet ført op på byens mur, hvor han ser en engel borttage de helligste ting fra templet og befale jorden at opsluge dem, så de engang kan blive givet tilbage, når Jerusalem skal genoprettes for evigt (SyrBar 6,5-10). I denne udgave er der ingen menneskelige aktører indblandet; og skjulestedet er her jorden under selve templet.

Flere passager i Talmud beskæftiger sig med arkens og de øvrige hellige ting fra Salomos tempel. Ifølge bJoma 21b var der fem ting, som kun fandtes i det første tempel (og ikke i det andet), nemlig arken med sonedækket og keruberne, ilden, det guddommelige nærvær (השכינה), den hellige ånd samt urim og tummim. Hvad der konkret skete med disse ting ved eksilet, er der forskellige meninger om. En udtrykkelig diskussion er refereret i bJoma 53b:

Rabbi Eliezer siger: Arken blev ført bort til Babylon, for det hedder: "Året efter sendte kong Nebukadnesar nogle folk, som førte ham til Babylon tillige med de kostbare kar fra Herrens tempel” (2 Krøn 36,10). Rabbi Simeon siger: Arken blev ført bort til Babylon, for det hedder: "Intet bliver tilbage (לא יותר דבד), siger Herren" (2 Kong 20,17). Det betyder de ti bud (אלו עשרת הדברות), som var i den. Rabbi Juda ben Laqish siger: Arken blev gemt på sit eget sted (במקומו נשנז), for det hedder: "Bærestængerne var så lange, at deres ender kunne ses fra det hellige foran det inderste rum, men de kunne ikke ses udefra" (1 Kong 8,8) (bJoma 53b).

bJoma 53b beretter også mere specifikt, at arken var gemt "i træmagasinet” (בלשכת דיר העצים). Traditionen støttes af en beretning om en uheldig præst, der uforvarende stødte på arkens gemmested og faldt $\mathrm{d} ø \mathrm{~d}$ om. Denne samme fortælling er gengivet i bSheqalim 6,1-2, der også har traditionen om træmagasinet som arkens gemmested:

Der var tretten indsamlingsbøsser, tretten borde og tretten bøjninger (השתחויות) i helligdommen. De, der hørte til Rabban Gamaliels hus, og de, der hørte til rabbi Hananias hus, præsternes stedfortræder, bøjede 
sig fjorten gange. Og i hvilken retning var den ekstra (bøjning)? I retning af træmagasinet (כנגד דיר העצים), for sådan var overleveringen hos dem fra deres fædre - at der var arken gemt (ששם הארון נגנזיר) (כשנז). Det hændte for en præst, der var i arbejde, at han så, at brolægningen adskilte sig fra den øvrige. Han kom og fortalte det til en kollega. Han nåede ikke at gøre beretningen færdig, før han udåndede. Da vidste de med bestemthed, at arken var gemt der (bSheqalim 6,1-2).

De talmudiske passager, der regner med, at de helligste genstande fra Salomos tempel ikke blev ødelagt eller bortført men blev gemt af vejen, fokuserer således primært på selve tempelområdet som gemmested. ${ }^{29}$ Disse tekster vidner - som den endnu senere Massekhet Kelim - om, hvordan legendedannelsen må have fortsat over lang tid, og om, hvordan de forskellige motiver kunne varieres og kombineres på forskellige måder. ${ }^{30}$

\section{Kobberrullens kontekst II: Qumran- teksterne og den antikke jødedom}

Kobberrullen synes, hvis den foreslåede tolkning er holdbar, at indeholde en forestilling om et tempel i ruiner og en generel forfaldstilstand, omfattende Jerusalem og det forjættede land som helhed. Perspektivet modsvares af et håb - som kommer indirekte til udtryk gennem befalingerne om at drage de skjulte tempelskatte frem i lyset fra deres gemmesteder - om en fremtidig forløsning. Lignende motiver finder vi også i andre Qumran-tekster. Således indeholder Tanhumim (4Q176) en beskrivelse af det ødelagte tempel, holdt i klagesalmens form med direkte tiltale til Gud:

29. Talmud kender ligesom den apokryfe litteratur til en forestilling om, at de ting, Gud har skænket Israel, ikke kan falde i fjendernes hænder. bSota 9a fastslår, at fjenderne ingen magt har "over Moses' og Davids gerninger”. Pointen illustreres med en henvisning til templets porte, der ikke blev ødelagt men sank i jorden (Jf. Klages. 2,9), og åbenbaringsteltet, der blev gemt af vejen efter bygningen af det første tempel. Gemmestedet var "under helligdommens krypter" (תחת מחילות של ההיכל).

30. Der har formentlig eksisteret en eller flere samaritanske legender om, at de hellige ting blev gemt på Garizims bjerg. En sådan legende synes at ligge bag Josefus' beretning om Pilatus' massakre på samaritanerne (Antiquitates VIII 85-89). Ifølge en senere samaritansk tradition gemte ypperstepræsten Uzzi de ting, som Moses havde lavet, på Garizim (John Macdonald, The Samaritan Chronicle No. II (or Sepher ha-Yamim): from Joshua to Nebuchadnezar, BZAW 107 (Berlin: De Gruyter 1961), 115. Jf. Marilyn F. Collins, "The Hidden Vessels in Samaritan Tradition", JSJ 3 (1972), 97-116; Day 2007, 250-251). 
Gør dit under, og øv retfærdighed i dit folk ... din helligdom. Gå i rette med kongedømmer i anledning af blodet ... Jerusalem. Se ligene af dine præster ... og ingen begraver dem (4Q176 1-2 i 1-4). ${ }^{31}$

Her er åbenbart tale om en liturgisk tekst, der afspejler forestillingen om et tempel og et land i ruiner. Tilsvarende toner slås an i Apokryfe Klagesange (4Q179), som er en klage over det ødelagte Jerusalem med en række tydelige allusioner til gammeltestamentlige tekster. Der er næppe grund til at tro, at disse Qumran-tekster afspejler en særlig historisk situation; det ødelagte tempel og land virker i højere grad som en metafor for det brudte pagtsforhold og det marginaliserede gudsfolk. ${ }^{32}$ Forventningen om en fornyelse af templet og landet kan til gengæld minde om den vision for et fornyet tempel, vi finder i Tempelrullen. Kobberrullens billede af et land i ruiner og et utilgængeligt, ødelagt Jerusalem kunne sagtens læses i denne kontekst. Selv om teksten ikke indeholder nogen af de udtryk, der kendetegner den særlige "sekteriske" Qumran-terminologi, har det været muligt at forstå og tolke skriftet inden for rammerne af Qumransamfundets verdensforståelse. Fremstillingen af en skriftrulle i kostbart metal - måske med en høj grad af symbolværdi - som efter alt at dømme må have fundet sted i Qumran, tyder i hvert fald på, at Kobberrullen her er blevet værdsat højt.

I bredere forstand må Kobberrullen, læst i dette perspektiv, siges at indskrive sig i en velkendt antik jødisk tradition, der beskæftiger sig med Salomos tempel og de legendariske kostbarheder herfra. Det er bemærkelsesværdigt, at denne tradition tilsyneladende florerede i ret forskellige udgaver, og at den i hvert fald i nogle jødiske kredse synes at have haft den pointe, at det eksisterende tempel savnede fuld legitimitet. ${ }^{33}$ Det er ikke vanskeligt at forestille sig, at netop dette perspektiv må have været attraktivt for Qumransamfundet, der har kunnet kombinere det med en generelt kritisk holdning til Jerusalems tempelkult og præsteskab.

31. Bodil Ejrnæs' oversættelse er fulgt. Se Dødehavsskrifterne og de antikke kilde om essaerne. 2. udvidede og reviderede udgave, red. Bodil Ejrnæs m.fl. (København: Anis 2008), 242.

32. Jf. hertil Jesper Høgenhaven, "Communal laments from Qumran and their biblical background", Plogbillar och svärd. En festskrift till Stig Norin, red. Tal Davidovich (Farsta: Molin \& Sorgenfrei 2012), 78-88. Se om 4Q176 Jesper Høgenhaven, "4QTanhumim (4Q176) between Exegesis and Treatise", The Mermaid and the Partridge: Essays from the Copenhagen Conference on Revising Texts from Cave Four, red. George Brooke \& Jesper Høgenhaven, STDJ 96 (Leiden: Brill 2011), 151-167.

33. Dette perspektiv fremhæves af Eshel og Safrai 2007. 